\title{
Predictors of Potential Drug-Drug Interactions in Patients at Intensive Care Unit
}

\author{
Ivana Iličković ${ }^{1}$, Vesna Orlandić-Čejović², Sanja Tanaskovićs ${ }^{3}$ Slobodan M. Janković ${ }^{3}$ \\ ${ }^{1}$ Evropa Lek Pharma, Podgorica, Montenegro \\ ${ }^{2}$ Clinical Center, Podgorica, Montenegro \\ ${ }^{3}$ University of Kragujevac, Faculty of Medical Sciences, Kragujevac, Serbia
}

\section{SUMMARY}

Drug-drug interactions (DDIs) with serious adverse consequences for patients at intensive care unit (ICU) occur with the prevalence of $5.3 \%$. The aim of our study was to reveal the risk factors for potential DDIs among the ICU patients.

This retrospective cohort analysis took place in the ICU of the Clinical Center Podgorica, Montenegro, between June 1, 2017 and September 30, 2018. The study was conducted as a chart review of the ICU patients $(\mathrm{n}=$ 99) who spent $\geq 2$ days in the ICU. The main outcome measure was the number of DDIs per patient.

Ninety-four percent of patients had at least one potential DDI, while $20 \%$ of patients had at least one potential DDI which required a change of therapy. The number of potential DDIs per patient according to the Medscape was $6.6 \pm 9.1$ and $3.8 \pm 4.9$ according to the Epocrates. A higher number of drugs (or therapeutic groups) prescribed per patient increased the number of potential DDIs, including those which required a change of therapy.

The patients who were prescribed antiarrhythmics, anticoagulants or two antiplatelet drugs experienced more DDIs than patients without these therapeutic groups, while delirium, dementia and drug allergy were protective factors. The main limitation of our study was its uni-centerdness, which allowed for certain degree of bias.

Routine screening of the ICU patients with high number of prescribed drugs who receive antiarrhythmics, anticoagulants or double antiplatelet therapy for potential DDIs may prevent a great deal of DDIs with potentially deleterious effects.

Key words: drug-drug interactions, risk factors, intensive care unit 


\section{INTRODUCTION}

Drug-drug interactions (DDIs) with serious adverse consequences for patients at intensive care unit (ICU) occur with high prevalence of $5.3 \%$ and are responsible for almost $15.5 \%$ of all adverse drug reactions in that patient population (1). In principle, DDIs are all preventable if potential for their occurrence is noticed on time (2). There are numerous softwares providing for rapid, bed-side discovery of clinically relevant potential DDIs, which were already validated in practice, and demonstrated significant sensitivity and specificity. However, such tools differ among themselves in severity classification of DDIs and recommendations, and their use should be considered as a screening procedure only (3).

As with any screening tool, effectiveness of DDI checkers is much higher if used in subpopulations with high risk of the target problem. Risk factors for DDIs in patients at ICU were studied in several settings, and the following were repeatedly reported: the length of stay and number of drugs or therapeutic groups prescribed (3-6). However, a few other risk factors may be of importance, especially prescription of certain drug groups which are prone to DDIs, like anticonvulsants or anticoagulans (3), but their true significance remain to be elucidated. The aim of our study was to test the significance of previously identified risk factors for potential DDIs, as well as to search for other not yet investigated risk factors which could help with more precise definition of subpopulation of the ICU patients with high risk for DDIs.

\section{METHODS}

We conducted retrospective cohort analysis of patients treated at the Intensive Care Unit of the Clinical Center (CC), a public tertiary care hospital in Podgorica, Montenegro. The cohort consisted of all consecutive patients who were admitted to the 34 -beds ICU between June 1, 2017 and September 30, 2018. The Ethics Committee of Clinical Center Podgorica had approved the study prior to its onset (No 03/01-1055/1 on 13.03.2017.).

The data used for the study were collected from the patient's files. The data about the patients' drug treatment, sociodemographic characteristics, and current conditions which could be potential risk factors for the occurrence of drug-drug interactions were entered in the study database. The drugs were classified according to the Anatomical Therapeutic Chemical Classification codes (ATC) (7). The following variables were followed in this study: socio-demographic data of the patients (age, gender), clinical history data (main diagnosis, length of stay in the hospital, mechanical ventilation, transfer from other departments to the ICU, state of consciousness, previous surgery), comorbidities (especially the presence of dementia or delirium, renal failure, liver failure, diabetes mellitus, chronic obstructive pulmonary disease, bronchial asthma, heart failure, hypertension), Charlson Comorbidity Index (8), and hospital medication details (total number of prescribed drugs, number of different pharmacological/therapeutic subgroups [2 $2^{\text {nd }}$ level of ATC classification] prescribed, prescription of antiplatelet drugs, anticoagulants, antiepileptic drugs, antidepressants, antiarrhythmic drugs (other drug groups could not be used as variables, because either such drugs were prescribed to almost every patient, e.g. analgesics or antibiotics, or just a few patients (or nobody) received particular drug group), drug-related allergy, number of physicians who prescribed therapy to a particular patient, and interaction checker data (number and description of the DDI). Prescribed drugs were administered according to the recommendations of Summaries of product characteristics (SPCs) issued by Montenegrin Drug Agency, starting with first doses for each day at 8 a.m.

The potential DDI in our study was defined as a possible interaction between two drugs, which might cause an alteration of the therapeutic effect and/or the toxicity of one or both of the drugs involved. The presence and classification of drug-drug interactions was determined by parallel use of two relevant interaction checker databases which operate on the principle of Internet and Smartphone applications: Medscape (9) and Epocrates (10). Medscape had categories of the severity of DDIs as Contraindicated, Serious - Use alternative, Monitor closely and Minor, and Epocrates as Contraindicated, Avoid/ use alternative, Monitor/modify therapy and Caution advised. We clustered Contraindicated and Serious - use alternative DDIs according to Medscape as "potential DDIs that require change of drug therapy", as well as Contraindicated and Avoid/ use alternative according to Epocrates. The drug-enteral nutrition interactions were not observed in the study.

\section{Statistics}

The study data were in the first place tabulated and analyzed by descriptive statistics. Mean and median were used as a measure of central tendency and standard deviation and range as measures of dispersion for continuous variables. Values of categorical variables were presented as numbers or percentages. Multiple li- 
near regression analysis was used to investigate the influence of potential risk factors on number of drug-drug interactions per patient. Statistical validity of the regression model was tested by analysis of variance ( $F$ value) and percentage of explained variability of the outcome $\left(\mathrm{R}^{2}\right)$. The influence of potential risk factors on the number of DDIs per patient was assessed by their B coefficients within the regression equation, including confidence intervals (CIs). All calculations were performed by the Statistical Program for Social Sciences (SPSS version 18).

\section{RESULTS}

The study sample included 99 patients (32 females and 67 males) hospitalized at Intensive Care Unit (ICU) of Clinical Center in Podgorica, Montenegro. An average age of the patients was $56.0 \pm 18.2$ years. Ninetyfour percent of patients had at least one potential DDI, while $20 \%$ of patients had at least one potential DDI which required a change of therapy. Detailed characteristics of the study patients are shown in Table 1.

Table 1. Characteristics of the study sample

\begin{tabular}{|c|c|c|}
\hline PARAMETER & $\begin{array}{c}\text { VALUE } \\
\text { (mean } \pm \text { SD or } \\
\text { number) }\end{array}$ & $\begin{array}{c}\text { VALUE } \\
\text { (median and } \\
\text { range or percent) }\end{array}$ \\
\hline Age (years) & $56,0 \pm 18.2$ & $61(5-88)$ \\
\hline $\operatorname{Sex}(\mathrm{M} / \mathrm{F})$ & $6 . / 32$ & $68 \% / 32 \%$ \\
\hline $\begin{array}{l}\text { Total number of potential DDIs per patient according } \\
\text { to Medscape }\end{array}$ & $6.6 \pm 9.1$ & $4(0-43)$ \\
\hline $\begin{array}{l}\text { Total number of potential DDIs per patient according } \\
\text { to Epocrates }\end{array}$ & $3.8 \pm 4.9$ & $2(0-28)$ \\
\hline $\begin{array}{l}\text { The number of potential DDIs per patient that require } \\
\text { a change of drug therapy according to Medscape }\end{array}$ & $0.9 \pm 1.2$ & $1(0-7)$ \\
\hline $\begin{array}{l}\text { The number of potential DDIs per patient that require } \\
\text { a change of drug therapy according to Epocrates }\end{array}$ & $0.9 \pm 1.2$ & $1(0-5)$ \\
\hline An average number of drugs per patient & $7.8 \pm 3.5$ & $8(2-17)$ \\
\hline An average number of prescribers per patient & $1.9 \pm 0.7$ & $2(1-4)$ \\
\hline $\begin{array}{l}\text { An average number of therapeutic groups (according } \\
\text { to the ATC classification) prescribed per patient }\end{array}$ & $6.0 \pm 2.5$ & $6(0-13)$ \\
\hline Charlson Comorbidity Index & $3.1 \pm 2.7$ & $3(0-9)$ \\
\hline The length of stay in the hospital (days) & $7.7 \pm 5.3$ & $6(1-28)$ \\
\hline Diagnosis of deliruim or dementia (yes/no) & 4. / 95 & $4 \% / 96 \%$ \\
\hline Transferred to the ICU from other ward (yes/no) & 42. / 57 & $42 \% / 58 \%$ \\
\hline $\begin{array}{l}\text { Physically restrained for at least one day during } \\
\text { hospitalization (yes/no) }\end{array}$ & 42. / 57 & $42 \% / 58 \%$ \\
\hline Confined to the bed (yes/no) & $91 . / 8$ & $92 \% / 8 \%$ \\
\hline Any degree of renal failure (yes/no) & $26 . / 73$ & $26 \% / 74 \%$ \\
\hline Having surgery (yes/no) & $64 . / 35$ & $65 \% / 35 \%$ \\
\hline Receiving anticoagulants (yes/no) & $64 . / 35$ & $65 \% / 35 \%$ \\
\hline Receiving double antiplatelet therapy (yes/no) & 10. / 89 & $10 \% / 90 \%$ \\
\hline Smoker (yes/no) & $20 . / 79$ & $20 \% / 80 \%$ \\
\hline Alcoholic (yes/no) & 9. / 90 & $9 \% / 91 \%$ \\
\hline Receiving anticonvulsants (yes/no) & $33 . / 66$ & $33 \% / 67 \%$ \\
\hline Receiving antiarrhythmics (yes/no) & 13. / 86 & $13 \% / 87 \%$ \\
\hline Drug allergy (yes/no) & $2 / 97$ & $2 \% / 98 \%$ \\
\hline
\end{tabular}


Table 2. Predictor variables with significant influence on the number of potential DDIs according to the drug checker used and degree of severity

\begin{tabular}{|c|c|c|c|c|}
\hline $\begin{array}{l}\text { DDI CHECKER } \\
\text { USED AND } \\
\text { SEVERITY OF } \\
\text { DDIs }\end{array}$ & $\begin{array}{c}\text { PREDICTOR } \\
\text { VARIABLE }\end{array}$ & $\begin{array}{l}\text { UNSTANDARDIZED } \\
\text { „B“ COEFFICENT }\end{array}$ & $\begin{array}{c}\text { CONFIDENCE } \\
\text { INTERVAL (95\%) }\end{array}$ & P - VALUE \\
\hline \multirow{5}{*}{$\begin{array}{c}\text { Medscape - all } \\
\text { degrees of severity }\end{array}$} & $\begin{array}{l}\text { The number of drugs } \\
\text { prescribed per patient }\end{array}$ & 1.023 & $0.526-1.521$ & 0.000 \\
\hline & $\begin{array}{c}\text { The number of } \\
\text { therapeutic groups ( } A T C \\
\text { classification) prescribed } \\
\text { per patient }\end{array}$ & 1.277 & $0.621-1.933$ & 0.000 \\
\hline & $\begin{array}{c}\text { Prescription of double } \\
\text { antiplatelet therapy }\end{array}$ & 6.034 & $1.990-10.079$ & 0.004 \\
\hline & Drug allergy & -12.205 & $-20.008--4.402$ & 0.003 \\
\hline & $\begin{array}{l}\text { Prescription of } \\
\text { antiarrhytmics }\end{array}$ & 9.924 & $5.336-14.512$ & 0.000 \\
\hline \multirow{2}{*}{$\begin{array}{c}\text { Epocrates - all } \\
\text { degrees of severity }\end{array}$} & $\begin{array}{l}\text { The number of drugs } \\
\text { prescribed per patient }\end{array}$ & 1.187 & $0.940-1.434$ & 0.000 \\
\hline & $\begin{array}{c}\text { Diagnosis of deliruim or } \\
\text { dementia }\end{array}$ & -6.393 & $-10.562--2.224$ & 0.003 \\
\hline \multirow{2}{*}{$\begin{array}{l}\text { Potential DDIs that } \\
\text { require a change of } \\
\text { drug therapy } \\
\text { according to the } \\
\text { Medscape }\end{array}$} & $\begin{array}{l}\text { Prescription of } \\
\text { anitarrhytmics }\end{array}$ & 1.085 & $0.320-1.849$ & 0.006 \\
\hline & $\begin{array}{l}\text { Prescription of } \\
\text { anticoagulant therapy }\end{array}$ & 0.860 & $0.307-1.414$ & 0.003 \\
\hline \multirow{5}{*}{$\begin{array}{l}\text { Potential DDIs that } \\
\text { require a change of } \\
\text { drug therapy } \\
\text { according to the } \\
\text { Epocrates }\end{array}$} & Sex of a patient & 0.462 & $0.039-0.885$ & 0.033 \\
\hline & $\begin{array}{l}\text { The number of drugs } \\
\text { prescribed per patient }\end{array}$ & 0.153 & $0.088-0.218$ & 0.000 \\
\hline & $\begin{array}{l}\text { The number of } \\
\text { therapeutic groups } \\
\text { (ATC classification) } \\
\text { prescribed per patient }\end{array}$ & 0.101 & $0.005-0.196$ & 0.039 \\
\hline & $\begin{array}{l}\text { Prescription of double } \\
\text { antiplatelet therapy }\end{array}$ & 1.278 & $0.721-1.836$ & 0.000 \\
\hline & Drug allergy & -1.612 & $-2.734--0.490$ & 0.006 \\
\hline
\end{tabular}

When the number of potential DDIs per patient according to the Medscape interaction checker was taken as the outcome variable, multiple linear regression model $\left(\mathrm{R}^{2}=0.773, \mathrm{~F}=33.012, \mathrm{p}=0.000\right)$ included the following independent and confounding variables: the number of drugs prescribed per patient, number of therapeutic groups (according to the ATC classification) prescribed per patient, prescription of double antiplatelet therapy, drug allergy, smoking and prescription of antiar- rhythmics. Unstandardized B coefficients, their $95 \%$ confidence intervals and p-values are shown in Table 2 only for variables with significant influence on the outcome variable, for the purpose of clarity.

Multiple linear regression model with the total number of potential DDIs per patient according to the Epocrates interaction checker was slightly less explanatory $\left(R^{2}=0.645, F=36.872, p=0.000\right)$, and included the following predictors: the number of drugs prescribed 
per patient, prescription of double antiplatelet therapy and diagnosis of delirium or dementia. However, only the number of drugs prescribed per patient and diagnosis of delirium or dementia were significant predictors, as shown in Table 2.

When the number of potential DDIs per patient that require a change of drug therapy according to the Medscape was taken as the outcome variable, a multiple linear regression model $\left(\mathrm{R}^{2}=0.402, \mathrm{~F}=7.918, \mathrm{p}=0.000\right)$ included the following independent and confounding variables: the number of therapeutic groups (according to the ATC classification) prescribed per patient, prescription of double antiplatelet therapy, prescription of antiarrhythmics, prescription of anticoagulant therapy and Charlson Comorbidity Index. Unstandardized B coefficients, their 95\% confidence intervals and p-values are shown in Table 2 only for variables with significant influence on the outcome variable, again for the purpose of clarity.

Finally, the multiple linear regression model with the number of potential DDIs per patient that require a change of drug therapy according to the Epocrates was more explanatory than that with Medscape and therapychanging DDIs ( $\mathrm{R}^{2}=0.662, \mathrm{~F}=18.892, \mathrm{p}=0.000$ ), and included the following predictors: sex of a patient, number of drugs prescribed per patient, number of therapeutic groups (according to the ATC classification) prescribed per patient, prescription of double antiplatelet therapy, drug allergy and prescription of an anticonvulsant. However, only the sex of a patient, number of drugs prescribed per patient, number of therapeutic groups (according to the ATC classification) prescribed per patient, prescription of double antiplatelet therapy and drug allergy were significant predictors, as shown in Table 2.

The most frequent potential DDIs found in our study that require a change of drug therapy according to Medscape and Epocrates interaction checkers are shown in Table 3.

Table 3. Top five potential DDIs that require a change of drug therapy according to Medscape and Epocrates interaction checkers, found in our study

\begin{tabular}{c|c}
\hline \hline MEDSCAPE & EPOCRATES \\
\hline $\begin{array}{c}\text { ceftriaxone or cefuroxime + enoxaparine } \\
\text { (ceftriaxone and cefuroxime increase the effects } \\
\text { of enoxaparin) }\end{array}$ & $\begin{array}{c}\text { clopidogrel + enoxaparine (increased the risk of } \\
\text { bleeding) }\end{array}$ \\
\hline $\begin{array}{c}\text { phenobarbital + enoxaparine (phenobarbital } \\
\text { decreases effects of enoxaparin by increasing } \\
\text { metabolism) }\end{array}$ & $\begin{array}{c}\text { clopidogrel + fluconazole (decreased clopidogrel } \\
\text { efficacy by inhibition of metabolism) }\end{array}$ \\
$\begin{array}{c}\text { propofol + norepinephrine (propofol increases } \\
\text { plasma levels of norepinephrine by decreasing } \\
\text { metabolism) }\end{array}$ & $\begin{array}{c}\text { benzodiazepines + tramadol (increased sedation } \\
\text { and risk of respiratory depression) }\end{array}$ \\
\hline $\begin{array}{c}\text { ceftriaxone + calcium gluconate (chemical } \\
\text { incompatibility and precipitation of drug } \\
\text { complexes in tissues) }\end{array}$ & $\begin{array}{c}\text { ceftriaxone + calcium gluconate (chemical } \\
\text { incompatibility and precipitation of drug } \\
\text { complexes in tissues) }\end{array}$ \\
\hline $\begin{array}{c}\text { furosemide + gentamycin (increased } \\
\text { ototoxicity and nephrotoxicity) }\end{array}$ & $\begin{array}{c}\text { beta blockers + insulin (prolonged } \\
\text { hypoglycemia and masked hypoglycemia) }\end{array}$ \\
\hline \hline
\end{tabular}

\section{DISCUSSION}

Our study confirmed the findings of others that the larger number of drugs (or therapeutic groups) prescribed per patient increases the number of potential
DDIs in ICU patients, including those which require a change of therapy. However, we also found that the patients who were prescribed antiarrhythmics, anticoagulants or two antiplatelet drugs experienced more DDIs than patients without these therapeutic groups. On the other hand, delirium or dementia and drug allergy were 
protective factors, which largely decreased the chances of and the number of DDIs. Finally, the male sex increased the chances of DDIs in ICU patients.

While the number of prescribed drugs or drug groups is linked to chances of DDIs for purely mathematical (statistical) reasons (11), an increased number of DDIs after prescription of antiarrhythmics, anticoagulants or antiplatelet drugs could be explained by high potential of these drugs to interact both pharmacokinetically and pharmacodynamically with numerous drugs from other groups. Indeed, studies of ICU patients showed that agents acting on the cardiovascular system, aggregation and coagulation are the most frequently engaged in DDIs $(12,13)$ because coagulation and platelet aggregation are complex processes with multiple regulatory points (where many drugs may interfere) and heart rhythm is based on coordinated functioning of ion channels, which are target of action not only of antiarrhythmics, but of anticonvulsants, anesthetics, psychotropic drugs, and others (14). Although only $10 \%$ of our patients received double antiplatelet therapy and only $13 \%$ antiarrhythmic drugs, DDIs from these groups were among the top five (Table 3).

Delirium and dementia are drug-induced in about $10 \%$ of cases (15), but, paradoxically, when observed in a patient, they may have protective effect against DDIs, as observed in our study. Deleterious effects of delirium in ICU patients were recognized, and current guidelines for treatment of such patients require among other careful analysis adjustment of drug therapy as well, which decreases the chances of DDIs (16). Routine checking of prescribed drug therapy for DDIs in ICU patients with the signs of delirium or dementia is increasingly performed in various healthcare settings (17).

Protective effect of drug allergy status of an ICU patient against DDIs could be explained by increased attention of prescribers to all aspects of drug therapy when prescribing to such patients. Prescribers not only avoid all drugs and drug groups which may cross-react with the drug a patient is allergic to, but also check for potential DDIs, which is not a routine procedure otherwise (18).

Although in our study male sex turned to be a weak risk factor for potential DDIs in ICU patients, other studies gave conflicting results, either showing no influence of gender, or favoring either female or male sex interchangeably (19) (3) (20). Further studies are necessary to clarify the influence of gender to DDIs in ICU patients.

The main limitations of our study were its unicenterdness, which allows for certain degree of bias introduced by local policies and practices, and a relatively small study sample, dictated by admission rate to the ICU in Podgorica. A larger sample of ICU patients would in-crease statistical power and allow for inclusion of more potential risk factors in the regression analysis.

\section{CONCLUSION}

In conclusion, our study showed that ICU patients with a high number of prescribed drugs who receive antiarrhythmics, anticoagulants or double antiplatelet therapy are at higher risk of experiencing DDIs. Routine screening of such patients for potential DDIs by means of drug-drug interaction checking software may prevent a number of DDIs with potentially deleterious effects and increase their chances for survival and recovery.

\section{Human rights}

The study was approved by the ethical review board.

A name and date approval granted by the ethical board is included in the manuscript.

A written or verbal informed consent was not obtained from each patient included in the study, because the study was retrospective and based on documentation only. The written informed consent was not necessary because no patient data has been included in the manuscript.

The study protocol conforms to the ethical guidelines of the 1975 Declaration of Helsinki as reflected in a priori approval by the institution's human research committee.

\section{Acknowledgements}

This study was done as a part of billateral scientific project (contracted by Republic of Serbia and Republic of Montenegro) entitled "Risk factors for drugdrug interactions in patients of tertiary-care hospitals".

\section{Funding}

The study was funded by the billateral scientific project (contracted by Republic of Serbia and Republic of Montenegro) entitled "Risk factors for drug-drug interactions in patients of tertiary-care hospitals".

\section{Authorship}


All of the authors did the following:

(i) contributed to the concept or design of the work, acquisition, analysis and interpretation of data;

(ii) Drafted the article and revised it critically for important intellectual content;

(iii) Approved the version to be published;

(iv) Each author participated sufficiently in the work to take public responsibility for appropriate portions of the content.

\section{Availability of data and materials}

The table with original data is available from the corresponding author on request.

\section{Informed consent}

The study was conducted in accordance with the principles of Helsinki Declaration for research on human subjects. Written or verbal informed consent was not ob- tained from each patient included in the study, because the study was retrospective and based on documentation only. Written informed consent was not necessary because no patient data has been included in the manuscript.

\section{Ethical approval}

The study was endorsed by the Ethics Committee of Clinical Center in Podgorica, No 03/01-1055/1 on 13.03.2017.

\section{Conflict of interest}

The authors declare that there is no conflict of interest. 


\section{References}

1. Reis AMM, Reis AMM, Cassiani SHDB. Adverse drug events in an intensive care unit of a university hospital. Eur J Clin Pharmacol. 2011;67:625-32. https://doi.org/10.1007/s00228-010-0987-y

2. Farcas A, Bucsa C, Sinpetrean A, et al. Preventability analysis of adverse drug reactions detected in two internal medicine departments in Romania. Intern Emerg Med. 2014;9:187-93. https://doi.org/10.1007/s11739-012-0843-4

3. Janković SM, Pejčić AV, Milosavljević MN, et al. Risk factors for potential drug-drug interactions in intensive care unit patients. J Crit Care. 2018; 43: 1-6. https://doi.org/10.1016/j.jcrc.2017.08.021

4. Reis AMM, Cassiani SHDB. Prevalence of potential drug interactions in patients in an intensive care unit of a university hospital in Brazil. Clin Sao Paulo Braz. 2011;66:9-15.

https://doi.org/10.1590/S1807-59322011000100003

5. Hassanzad M, Arenas-Lopez S, Baniasadi S. Potential Drug-Drug Interactions Among Critically Ill Pediatric Patients in a Tertiary Pulmonary Center. J Clin Pharmacol. 2018;58:221-7. https://doi.org/10.1002/jcph.996

6. Kuscu F, Ulu A, Inal AS, et al. Potential Drug-Drug Interactions with Antimicrobials in Hospitalized Patients: A Multicenter Point-Prevalence Study. Med Sci Monit Int Med J Exp Clin Res. 2018; 24: 4240-7.

https://doi.org/10.12659/MSM.908589

7. Rønning M, Blix HS, Harbø BT, Strøm H. Different versions of the anatomical therapeutic chemical classification system and the defined daily dose--are drug utilisation data comparable? Eur J Clin Pharmacol. 2000; 56: 723-7. https://doi.org/10.1007/s002280000200

8. Charlson ME, Pompei P, Ales KL, MacKenzie CR. A new method of classifying prognostic comorbidity in longitudinal studies: development and validation. J Chronic Dis. 1987; 40: 373-83. https://doi.org/10.1016/0021-9681(87)90171-8

9. Kothari N, Ganguly B. Potential Drug - Drug Interactions among Medications Prescribed to Hypertensive Patients. J Clin Diagn Res. 2014; 8: HC01-4. https://doi.org/10.7860//CDR/2014/10032.5091

10. Apidi NA, Murugiah MK, Muthuveloo R, et al. Mobile Medical Applications for Dosage Recommendation, Drug Adverse Reaction, andDrug Interaction: Review and Comparison. Ther Innov Regul Sci. 2017; 51: 480-485.

https://doi.org/10.1177/2168479017696266

11. Patel PS, Rana DA, Suthar JV, et al. A study of potential adverse drug-drug interactions among prescribed drugs in medicine outpatient department of a tertiary care teaching hospital. J Basic Clin Pharm. 2014; 5: 44-8.

https://doi.org/10.4103/0976-0105.134983

12. Gülçebi İdriz Oğlu M, Küçükibrahimoğlu E, Karaalp A, et al. Potential drug-drug interactions in a medical intensive care unit of a university hospital. Turk J Med Sci. 2016 ; 46: 812-9.

https://doi.org/10.3906/sag-1504-147

13. Smithburger PL, Kane-Gill SL, Seybert AL. Drugdrug interactions in the medical intensive care unit: an assessment of frequency, severity and the medications involved. Int J Pharm Pract. 2012; 20: 402-8. https://doi.org/10.1111/j.2042-7174.2012.00221.x

14. Dechanont S, Maphanta S, Butthum B, Kongkaew C. Hospital admissions/visits associated with drugdrug interactions: a systematic review and metaanalysis. Pharmacoepidemiol Drug Saf. 2014; 23: 489-97.

https://doi.org/10.1002/pds.3592

15. Back C, Wittmann M, Haen E. Delirium induced by drug treatment. Ther Umsch Rev Ther. 2011; 68: 2733.

https://doi.org/10.1024/0040-5930/a000116

16. Barr J, Fraser GL, Puntillo K, et al. Clinical practice guidelines for the management of pain, agitation, 
and delirium in adult patients in the intensive care unit. Crit Care Med. 2013; 41: 263-306.

https://doi.org/10.1097/CCM.0b013e3182a167d7

17. Pandharipande PP, Patel MB, Barr J. Management of pain, agitation, and delirium in critically ill patients. Pol Arch Med Wewn. 2014; 124: 114-23.

https://doi.org/10.20452/pamw.2136

18. Li M, Krishna MT, Razaq S, Pillay D. A real-time prospective evaluation of clinical pharmaco-economic impact of diagnostic label of "penicillin allergy" in a UK teaching hospital. J Clin Pathol. 2014 Dec; 67: 1088-92.

https://doi.org/10.1136/jclinpath-2014-202438
19. Cruciol-Souza JM, Thomson JC. Prevalence of potential drug-drug interactions and its associated factors in a Brazilian teaching hospital. J Pharm Pharm Sci Publ Can Soc Pharm Sci Soc Can Sci Pharm. 2006;9:427-33.

20. Reimche L, Forster AJ, van Walraven C. Incidence and contributors to potential drug-drug interactions in hospitalized patients. J Clin Pharmacol. 2011; 51: 1043-50. https://doi.org/10.1177/0091270010378858 


\title{
Prediktori mogućih interakcija između lekova kod pacijenata $u$ intenzivnoj nezi
}

\author{
Ivana Iličković ${ }^{1}$, Vesna Orlandić-Čejović², Sanja Tanaskovićs, Slobodan M. Janković3 \\ ${ }^{1}$ Evropa Lek Pharma, Podgorica, Crna Gora \\ ${ }^{2}$ Klinički centar, Podgorica, Crna Gora \\ ${ }^{3}$ Univerzitet u Kragujevcu, Fakultet medicinskih nauka, Kragujevac, Srbija
}

\section{SAŽETAK}

Interakcije između lekova (IIL) sa ozbiljnim posledicama po pacijente u intenzivnoj nezi (IN) događaju se sa prevalencijom od 5,3\%. Cilj naše studije bio je da otkrije faktore rizika za nastanak mogućih IIL kod pacijenata u IN.

Ova retrospektivna kohortna studija sprovedena je u IN Kliničkog centra Podgorica, Crna Gora, između 1. juna 2017. i 30. septembra 2018. godine. Studija je sprovedena $u$ vidu analize terapijskih lista pacijenata $(n=99)$, koji su proveli $\geq 2$ dana u IN. Glavni ishod studije bio je broj mogućih IIL po pacijentu.

Devedeset četiri procenta pacijenata imalo je bar jednu moguću IIL, dok je $20 \%$ pacijenata imalo bar jednu moguću IIL koja je zahtevala promenu terapije. Broj mogućih IIL po pacijentu prema Medscape softveru bio je 6,6 $\pm 9,1$, a 3,8 $\pm 4,9$ prema softveru Epocrates. Veći broj propisanih lekova (ili terapijskih grupa) po pacijentu bio je povezan sa većim brojem potencijalnih IIL, uključujući i one koje su zahtevale promenu terapije.

Pacijenti kojima su propisani antiaritmici, antikoagulansi ili dva antiagregaciona leka imali su više potencijalnih IIL nego pacijenti bez tih terapijskih grupa, dok su delirijum, demencija i alergija na lekove delovali protektivno. Glavno ograničenje naše studije je činjenica da je sprovedena samo $u$ jednom centru, što je moglo uneti neproporcionalno veliki uticaj lokalne kliničke prakse.

Rutinska kontrola mogućih IIL kod pacijenata u IN sa velikim brojem propisanih lekova, među kojima su antiaritmici, antikoagulansi i dvostruka antiagregaciona terapija, mogla bi sprečiti nastanak velikog broja IIL sa mogućim teškim posledicama.

Ključne reči: interakcije između lekova, faktori rizika, intenzivna nega 